\title{
RUOKINNAN VAIKUTUS SINIKETUN HORMONAALISEEN TASAPAINOON JA LISÄÄNTYMISEEN
}

\author{
Hannu T. Korhonen ${ }^{1}$, Pekka Eskeli ${ }^{1}$ ja Juhani Sepponen ${ }^{2}$ \\ ${ }^{1}$ Luonnonvarakeskus, Luke, Silmäjärventie 2, 69100 Kannus; hannu.t.korhonen@luke.fi \\ ${ }^{2}$ Luonnonvarakeskus, Luke, Halolantie 31 A, 71750 Maaninka
}

\section{TIIVISTELMÄ}

Tutkimuksessa tarkasteltiin siniketun elimistön tärkeimpiä sääteleviä hormoneja ja niiden vaikutusta lisääntymistulokseen. Kokeessa oli 228 sinikettunaarasta, jotka jaettiin kolmeen ryhmään. Ryhmä 1: "Voimakas laihdutus" Rajoittamaton ruokinta syyskuun alusta marraskuun loppuun asti, tavoitteena erittäin lihavat eläimet. Voimakas laihdutus ennen siitoskautta, tavoitteena ihanteellinen siitosajan paino. Ryhmä 2: "Kunnon ylläpitäminen" Ruokinnan rajoitus 35- 45 \% ryhmän 1. ruokinnasta loka-marraskuun loppuun asti. Kunnon ja painon ylläpito tammikuuhun asti. Luontainen laihtuminen ihanteelliseen siitosajan painoon. Ryhmä 3: "Nouseva kunto" Ruokinnan rajoitus 50-60 \% marraskuun loppuun asti, tavoitteena laihat eläimet. Eläimillä nouseva kunto tammikuulle mentäessä, tavoitteena ihanteellinen siitosajan paino. Tulosten mukaan ureapitoisuuksissa oli nähtävissä selvää vuodenaikaista vaihtelua. Pitoisuudet olivat alhaisimmat talvikaudella. Ryhmällä 1 voimakas paasto alensi eniten ureapitoisuuksia talvikauden alussa. Ryhmällä 3 voimakas ruokinnan rajoitus syyskaudella näkyi ureapitoisuuksissa. Kreatiniiniarvot olivat korkeimmillaan alku- ja keskikesästä kaikilla ryhmillä. Ryhmien välillä ei ollut mitään merkitsevää eroa. Glukoosipitoisuus vaihteli vuodenajoittain $(\mathrm{P}<0.001)$. Voimakas ruokinnan rajoitus vuodenvaihteessa kohotti ryhmän 1 glukoosipitoisuuksia. Syyskaudella voimakas ruokinta selvästi kohotti insuliinieritystä $(\mathrm{P}<0.01)$. Vuodenvaihteen paasto pudotti ryhmän 1 insuliinitasot normaaleiksi. Prolaktiinitasot olivat samalla tasolla kaikissa koeryhmissä keinosiemennykseen asti. Tiineyskaudella prolaktiinitasot kohosivat samalla lailla kaikissa ryhmissä, mutta penikoimisen jälkeen ryhmän 1 tasot olivat matalampia $(\mathrm{P}<0.05)$. Leptiinipitoisuus oli kaikilla ryhmillä korkeimmillaan vuodenvaihteessa ja laski kesää kohden. Kasvuhormonissa ei ollut tilastollista eroa koeryhmien välillä. IGF-1 -tasot olivat korkeimmillaan alkusyksystä. Ne tasaantuivat vuodenvaihteessa, mutta alenivat jälleen tiineysajan edetessä $(\mathrm{P}<0.001)$. Kasvukaudella alhaisimmat Triglyseridi $(\mathrm{TG})$-pitoisuudet olivat ryhmällä 3 , jota rajoitettiin kaikkein voimakkaimmin $(\mathrm{P}<0.01)$. Korkein pitoisuus taas oli vapaalla ruokinnalla. Alkuvuodesta alkanut paasto laski ryhmän 1 TG-tasoja. Ruokinnan tasolla ja paastolla on selvää vaikutusta kettujen hormonaaliseen tasapainoon ja lisääntymiseen.

Asiasanat: Sinikettu, lisääntyminen, ruokinnan voimakkuus, hormonit, hyvinvointi 


\section{Johdanto}

Useilla eläinlajeilla on osoitettu, että eläimen kunnolla ja ravitsemuksellisella tilalla on merkittävä vaikutus lisääntymistulokseen. Energian saanti, ruumiin kunto ja lisääntymistoiminnot ovat vahvasti kytköksissä toisiinsa (Blache ym. 2003). Hyvän lisääntymiskapasiteetin ylläpitäminen vaatii tasapainoa energiansaannin ja kulutuksen välillä. Jos energiaa ei ole riittävästi saatavilla, olemassa olevat elimistön energiareservit ohjataan elintärkeisiin toimintoihin (Wade ym. 1996). Äärimmäisissä tapauksissa negatiivinen energiatase eli laihdutus johtaa lisääntymistoimintojen lakkautumiseen.

Aineenvaihdunnan ylläpidon ja lisääntymistehokkuuden väliset yhteydet tarkoittavat monitasoisia umpierityksellisten ja aineenvaihdunnallisten ärsykkeiden yhteyksiä aineenvaihdunnan ja lisääntymisen hallitsemiseksi (Roche 2006). Näiden reaktioiden on väistämättä pidettävä sisällään merkinantomolekyylejä ja hormoneja, jotka ovat olennainen osa säätelyjärjestelmää. Merkinantomolekyylejä valmistetaan useissa elimissä, jotka osallistuvat ravinteiden käsittelyyn, varastointiin tai käyttöön sekä elimissä, jotka osallistuvat lisääntymistapahtumaan. Lisäksi varmistaakseen energian ja valkuaisaineiden osituksen täsmällisen säätelyn jokainen tietty merkinantomolekyyli on todennäköisesti vuorovaikutuksessa toisen merkinantomolekyylin/toisten merkinantomolekyylien kanssa (Korhonen ym. 2015).

Tutkimuksen tavoitteena oli tarkastella siniketun elimistön tärkeimpiä sääteleviä hormoneita ja niiden vaikutusta lisääntymistulokseen. Samoin seurattiin useita aineenvaihduntaa sääteleviä metaboliitteja, jotka voivat selittää eläimen aineenvaihdunnallista tilaa. Pyrittiin kytkemään eläimen ruokintahistoria ja siten kunto eläimen lisääntymistulokseen ja edelleen pentujen eloonjäämiseen.

\section{Aineisto ja menetelmät}

Kokeessa oli 228 sinikettunaarasta, jotka jaettiin kolmeen ryhmään (Korhonen ym. 2015). Ryhmä 1: "Voimakas laihdutus" Rajoittamaton ruokinta syyskuun alusta marraskuun loppuun asti, tavoitteena erittäin lihavat eläimet. Voimakas laihdutus ennen siitoskautta, tavoitteena ihanteellinen siitosajan paino. Ryhmä 2: "Kunnon ylläpitäminen" Ruokinnan rajoitus 35- 45 \% ryhmän 1. ruokinnasta loka-marraskuun loppuun asti. Kunnon ja painon ylläpito tammikuuhun asti. Luontainen laihtuminen ihanteelliseen siitosajan painoon. Ryhmä 3: "Nouseva kunto" Ruokinnan rajoitus 50-60 \% marraskuun loppuun asti, tavoitteena laihat eläimet. Eläimillä nouseva kunto tammikuulle mentäessä, tavoitteena ihanteellinen siitosajan paino.

Verinäytteet otettiin syksyn aikana kerran kuukaudessa, viimeinen verinäytteenotto vrk ennen kuin ruokinta eriytettiin marras-joulukuun vaihteessa ja sen jälkeen 1, 2, 3 ja 7 vrk laihdutuksen alkamisesta. Verinäytteitä otettiin joka toinen viikko, kunnes eläimet siemennettiin. Verinäytteet otettiin myös siemennyshetkellä. Tuolloin suurin osa eläimistä jouduttiin vaihtamaan, koska kokeessa jatkavien eläinten siemennysajankohdan haluttiin osuvan kahden päivän sisälle (13.-14.4.). Siemennetyiltä naarailta verinäytteet otettiin tiineysviikolla 3,5 ja 7 . Maidontuotannon aikana verinäytteet otettiin, kun pennut olivat 2 ja 4 viikon vanhoja sekä vieroitushetkellä. Jos verinäyteohjelmassa oleva naaras ei penikoinut tai hävitti pentunsa, otettiin näytteet toiselta naaraalta, jolla oli pennut.

Näytteenottokertoja oli kaikkiaan 22 kappaletta. Tilastollisia analyysejä varten koko tutkimusjakso jaettiin neljään lyhyempään jaksoon: syyskausi (ryhmällä 1 lihotus), talvikausi (ryhmällä 1 voimakas laihduttaminen), kevätkausi (tiineysaika) ja kesäkausi (penikoimisen jälkeinen aika) ja analyysit tehtiin erikseen kullekin jaksolle. Tulokset analysoitiin SAS-ohjelmiston MIXED-toistomittausmallilla.Tulokset analysoitiin SAS-ohjelmiston MIXED-toistomittausproseduurilla.

Tilastollinen malli oli

$\mathrm{y}_{i j k}=\mu+\tau_{i}+v_{k}+\varsigma_{i k}+\varepsilon_{i j k}$ 
missä $\mu$ on yleiskeskiarvo, $\tau_{i}$ käsittelyn i vaikutus, $v_{k}$ ajan k vaikutus, $\varsigma_{i k}$ käsittely x aika yhdysvaikutus ja $\varepsilon_{i j k}$ on jäännösvirhe.

Koska eläimiä kasvatettiin pareittain joulukuun alkuun asti, häkkikeskiarvoja käytettiin syyskauden analyyseissä. Varianssien homogeenisuuden saavuttamiseksi insuliini-, IFG-1-, prolaktiini- ja triglyseridiarvojen tilastoanalyyseissä käytettiin logaritmimuunnoksia kaikilla neljällä jaksolla. Logaritmimuunnoksia käytettiin talvi- ja kevätkaudella kasvuhormoni- ja glukoosiarvojen laskennassa, urealla lisäksi kesäkauden tulosten laskennassa (Korhonen ym. 2015).

\section{Tulokset ja tulosten tarkastelu}

Tulosten mukaan ureapitoisuuksissa oli nähtävissä selvää vuodenaikaista vaihtelua. Pitoisuudet olivat alhaisimmat talvikaudella. Ryhmällä 1 voimakas paasto alensi eniten ureapitoisuuksia talvikauden alussa. Ryhmällä 3 voimakas ruokinnan rajoitus syyskaudella näkyi ureapitoisuuksissa. Kreatiniiniarvot olivat korkeimmillaan alku- ja keskikesästä kaikilla ryhmillä. Ryhmien välillä ei ollut mitään merkitsevää eroa. Glukoosipitoisuus vaihteli vuodenajoittain $(\mathrm{P}<0.001)$. Voimakas ruokinnan rajoitus vuodenvaihteessa kohotti ryhmän 1 glukoosipitoisuuksia. Syyskaudella voimakas ruokinta selvästi kohotti insuliinieritystä $(\mathrm{P}<0.01)$. Vuodenvaihteen paasto pudotti ryhmän 1 insuliinitasot normaaleiksi. Prolaktiinitasot olivat samalla tasolla kaikissa koeryhmissä keinosiemennykseen asti. Tiineyskaudella prolaktiinitasot kohosivat samalla lailla kaikissa ryhmissä, mutta penikoimisen jälkeen ryhmän 1 tasot olivat matalampia $(\mathrm{P}<0.05)$. Leptiinipitoisuus oli kaikilla ryhmillä korkeimmillaan vuodenvaihteessa ja laski kesää kohden. Kasvuhormonissa ei ollut tilastollista eroa koeryhmien välillä. IGF-1 -tasot olivat korkeimmillaan alkusyksystä. $\mathrm{Ne}$ tasaantuivat vuodenvaihteessa, mutta alenivat jälleen tiineysajan edetessä $(\mathrm{P}<0.001)$. Kasvukaudella alhaisimmat Triglyseridi (TG)-pitoisuudet olivat ryhmällä 3, jota rajoitettiin kaikkein voimakkaimmin $(\mathrm{P}<0.01)$. Korkein pitoisuus taas oli vapaalla ruokinnalla. Alkuvuodesta alkanut paasto laski ryhmän 1 TG-tasoja.

Eläimen kunnolla ja ravitsemuksellisella tilalla on vaikutusta lisääntymiseen. Energian saanti, ruumiin kunto ja lisääntymistoiminnot ovat vahvasti kytköksissä toisiinsa. Aineenvaihdunnan ylläpidon ja lisääntymistehokkuuden väliset yhteydet tarkoittavat monitasoisia umpierityksellisten ja aineenvaihdunnallisten ärsykkeiden yhteyksiä aineenvaihdunnan ja lisääntymisen hallitsemiseksi. Sinikettujen lisääntymistulos yhdistetään korkeaan painoon syksyllä ja rankkaan laihdutukseen siitoskauden alla. Kattavaa selvitystä tarhakettujen hormonitasoista ja niiden vuodenaikaisvaihteluista suhteessa ruokintasoihin ja lisääntymiseen ei aiemmin ole ollut olemassa. Tämä tutkimus on sen vuoksi hyvin merkittävä ja tarjoaa arvokasta lisätietoa aiheesta.

Tämä tutkimus osoittaa, että tutkittujen hormonien avulla voidaan seurata ruokinnan vaikutusta eläimen hormonaaliseen ja energeettiseen tasapainoon ja osin myös ravitsemukselliseen stressiin. Liiallinen laihdutus eli negatiivinen energiatase näyttää johtavan heikentyneeseen lisääntymistulokseen (ryhmä 1). Se näkyy myös hormonipitoisuuksissa. Sinikettujen oikeaoppinen ruokinta syys- ja siitoskaudella kaipaa edelleen lisätutkimuksia. On kuitenkin selvää, että on vältettävä liian voimakasta, lyhytaikaista laihduttamista ja lihottamista. Tasainen ruokinta todennäköisimmin pitää sekä energia-aineenvaihdunnan että hormonit parhaiten tasapainossa.

\section{Johtopäätökset}

Tuotantokauden aikaisen ruokinnan vaikutus hormonaaliseen tasapainoon oli odotetunmukainen. Tulokset vaikuttavat pääosin loogisilta ja normaaleilta. Ruokinnan tasolla ja paastolla on selvää vaikutusta kettujen hormonaaliseen tasapainoon ja sitä kautta pentutuotokseen ja hyvinvointiin. 


\section{Kirjallisuus}

Blache, D., Zhang, S., Martin, G.B. 2003. Fertility in male sheep: modulators of the acute effects of nutrition on the reproductive axis of male sheep. Reprod. Suppl., 61, pp. 387-402.

Korhonen, H.T., Sepponen, J.,Eskeli, P. \& Koskinen, N. 2015. Effect of pine meal on production results and welfare in blue foxes (Vulpes lagopus). Scientifur 39(3): 37-42.

Roche JF. 2006. The effect of nutritional management of the dairy cow on reproductive efficiency. Anim. Reprod. Sci. 96:282-296.

Wade GN, Schneider JE, Li HY. 1996. Control of fertility by metabolic cues. Am. J. Physiol. Endocrinol. Metab. 270:1-19. 